\title{
原著
}

\section{早期胃癌における下部食道括約筋・幽門輪温存胃亜全摘術兼 有茎空腸間置術の病態生理学的検討}

\author{
日本大学第 1 外科 \\ 富 田凉一黒須 康 彦 \\ 滝沢秀博阿部義 蔵
}

\begin{abstract}
早期胃癌において, QOL の向上をめざした機能温存術式である下部食道括約筋 (LES)・幽門輪温存胃亜 全摘兼有茎空腸間置術施行症例 10 例と胃全摘兼有茎空腸間置術施行症例 12 例について, 術後の逆流性食道 炎と早期ダンピング症候群の発生を中心に，それぞれの術式を機能面から比較検討した。その結果, 胃全摘 兼有茎空腸間置術例では，1）明らかに逆流症状が多く，また逆流性食道炎と早期ダンピング症候群を多く認 めた，2）LES 長の短縮と LES 圧の低下，および下部食道のアルカリ化を認めた，3）再建空腸内容排出時間 の短縮を認めた，4）血中ガストリン值が経口捸取前と捸取 15 分後ともに明らかに低值を示した。以上より, 胃全摘兼有茎空腸間置術例よりも LES・幽門輪温存胃亜全摘兼空腸間置術は, より生理的な手術と考えら れた。
\end{abstract}

索引用語：括約筋温存術, 下部食道括約筋内圧, 24 時間 $\mathrm{pH}$ 測定, 再建空腸内容排出試験, ガストリン

\section{はじめに}

胃全摘術においては，胃とともに下部食道括約 筋 (lower esophageal sphincter: LES), 幽門括 約筋 (pyloric sphincter) に加えてリンパ節郭清に 伴って迷走神経なども切除される。よって, LES による胃食道逆流防止機構, 胃の貯留能や攪拌能, 幽門括約筋による胃内容排出調節機能, 迷走神経 による胃腸管運動や胃液分泌機構の調節などが久 落し, 種々の機能障害や器質的障害を招く。そし て, 前者では早期ダンピング症候群, 後者では逆 流性食道炎がそれらの代表的な障害として多く報

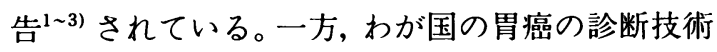
の進歩はめざましく，その約半数は早期胃癌であ ク, 当然のことながら術後の quolity of life （QOL）を念頭にいれた手術術式が選ばれなけれ ばならない。以前から, 胃全摘後の再建術式とし て食物が十二指腸を通過する空腸間置術が生理的 と考えられており 4 6),また, Maki らによより考案 された胃機能温存手術の1つである, 幽門輪温存 胃亜全摘兼有茥空腸間置 (pylorus preserving nearly total gastrectomy with jejunal interposition）が早期ダンピング症候群と逆流性食道炎の 防止に有効であると報告されている。今回, 著者 らは, この術式の変法として LES・幽門輪温存胃 亜全摘兼空腸間置術を考案施行しているので, 術 後における早期ダンピング症候群や逆流性食道炎 などの発生との関係を病態生理学的に検討した。

\section{対象と方法}

\section{1. 対象}

当科において 1989 年 1 月から 1994 年 12 月ま での過去 5 年間に経験した早期胃癌手術例 $\left(\mathrm{D}_{2}\right.$ リ ンパ節郭清, 根治度 A）のうち, 胃全摘兼有茎空 腸間置術施行症例 12 例（男性 10 例, 女性 2 例, 26 62 歳, 平均 59.6 歳; A 群), 下部食道括約筋 (LES) - 幽門輪温存胃亜全摘兼空腸間置術施行 症例 10 例 (男性 8 例, 女性 2 例, $34 \sim 69$ 歳, 平均 56.8 歳；B 群）を対象とした。対照（C 群）とし ては, 消化器症状や消化器病の既往がまったくな く, しかも検査に協力して頂いた健常人 10 例(男 性 10 例, 28 61 歳, 平均 49.8 歳）を用いた。な 
お，これらの対象症例のすべてにおいて術後合併 症（縫合不全, 吻合部狭窄など）がなく，また， 全例術後 6 年から 1 年 4 力月 (平均 3 年 4 力月) あまり経過した症例であり，さらにいずれにおい ても, 術後化学療法などは行われていない。

LES・幽門輪温存胃亜全摘兼空腸間置術術式 については, LES 部の温存と食道空腸吻合以外は Maki らの方法と同様に行った。すなわち, 食道空 腸吻合（端側機械吻合）する際には, 完全に食道 胃接合部が残されるように胃を切断した。

\section{2. 方 法}

1）問診: 逆流症状（胸やけ, 胸がしみる, 逆 流感, 食物通過時前胸部痛, 嶼下困難など), 早期 ダンピング症状(全身症状：冷汗, 動悸, めまい, しびれ・失神, 顔色が青くなる, 顔色が赤くなる, 全身が熱くなる，全身がだるく力が抜ける，眠く てたまらない, 頭痛・頭重, 胸苦しい, などで第 4 回日本消化器外科学会に基づく早期ダンピング 症候群の判定基準による）の有無 ${ }^{8 \sim 9)}$ を検査時に 被験者に直接面接して調査した。

2) LES の長さ (LESL) と圧 (LESP) の測定 食道内圧測定用のカテーテルは triple lumen であり polyvinyl tube を 3 本束ねたもので, $5 \mathrm{~cm}$ 間隔 (1 本目は先端から $1 \mathrm{~cm}, 2$ 本目は先端から 6 $\mathrm{cm}, 3$ 本目は先端から $11 \mathrm{~cm}$ に側孔がある）に側 孔があけられている (全長 $125 \mathrm{~cm}$, 内径 $1.6 \mathrm{~mm}$, 側孔 $1.6 \mathrm{~mm}$, esophageal manometry catheter, AMS 社, USA)。このカテーテルを三方活栓を介 して一方は pressure transducer (model, $1280 \mathrm{C}$, Hewlett-Packard 社, USA）に接続し，さらに pressure amplifier (model 8805, Hewlett-Packrd 社, USA) で増幅して, thirmal tip recorder (model 7754 A, Hewlett-Packard 社, USA)に て圧変動を記録した。他の一方は毎分 $0.35 \mathrm{ml}$ の 速度で蒸留水を持続注入した (pneumohydrauric capillary system, Arndorfer 社製, USA)。

3）下部食道持続 24 時間 $\mathrm{pH}$ 測定

下部食道 $\mathrm{pH}$ 測定システムとして Liberty System LS 2 およU゙アンチモン電極 (Synetics Medical 社, USA) を使用した。アンチモン電極は食道 空腸吻合部から $5 \mathrm{~cm}$ 上方の下部食道においた。 これを専用の computer soft（EsopHogram pro- gram, Synetics Medical 社, USA)により解析し, $\%$ 時間 $\mathrm{pH}>7$ を算出した。なお, 検査日の食事は 3 回/日として,オレンジジュース,ココア, 炭酸 飲料水などの $\mathrm{pH}$ に影響を及ぼすようなものはい つさい経口を禁じた。また, 経口薬も検査 2 日前 より中止させた。

\section{4）再建空腸内容排出率}

検查食 (全粥 $200 \mathrm{gr}+$ 鶏卵 1 個＋梅干し 1 個) に ${ }^{99 \mathrm{~m}} \mathrm{Tc}$ スズコロイド $1 \mathrm{mCi}$ を加え十分に覮挥し， 坐位で 5 分以内に全量を搨取させた。測定には日 立 HARP I を用い, カウントは仰臥位にて 1 方向 から 1 分間行った。測定時間は検査食摂取終了直 後を 0 分とし 120 分までとした。減衰曲線の percent activity から $50 \%$ となった時間を再建空腸 内残存率 $50 \%$ 時間 (half-jejunal empting time) とした。

5）血中ガストリン值測定

上記の検査を始める直前の空腹時と検査食経口 攝取 15 分後に採血し radioimmunoassay 法を用 いて測定した。

統計学的解析には, Student's t test 用い $\mathrm{p}<$ 0.05 をもって有意とした。

\section{成 績}

\section{1. 直接問診による臨床症状}

1）早期ダンピング症候群

陽性率は A 群 $16.7 \%(2 / 12), \quad B$ 群 $0 \%(0 / 10)$ であり，A 群に多く認めたが有意差はなかった。

2）食道逆流症状

陽性率は A 群 $41.7 \%(5 / 12), B$ 群 $0 \%(0 / 10)$ であり，A 群に有意に多く認めた $(\mathrm{p}<0.05)$ 。な お，食道内視鏡検査は全例に行われており， A 群 の逆流症状のある 4 例のうち 3 例が内視鏡的に色 調変化型の軽度食道炎所見を呈したが, 残りの 1 例では所見が認められなかった。

\section{2. 下部食道括約筋の長さと圧力}

1）下部食道括約筋長（LESL）（図 1)

$\mathrm{A}$ 群 $1.9 \pm 0.7 \mathrm{~cm}, \mathrm{~B}$ 群 $3.1 \pm 0.8 \mathrm{~cm}, \mathrm{C}$ 群 $4.0 \pm 0.5 \mathrm{~cm}$ で, A 群では B 群, C 群より（それ ぞれ $\mathrm{p}<0.01, \mathrm{p}<0.001)$ ，また， B 群では $\mathrm{C}$ 群よ り有意に短かった $(\mathrm{p}<0.05)$ 。

2）下部食道括約筋圧（LESP）（図 2) 


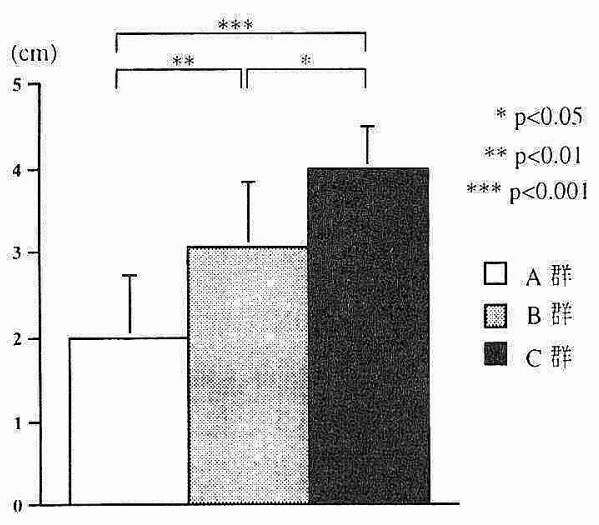

図 1 下部食道括約筋長 (LESL)

$\mathrm{A}$ 群：胃全摘兼有茎空腸間置術

$\mathrm{B}$ 群：LES・幽門輪温存胃覀全摘兼有茎空腸間置術 C群：対照

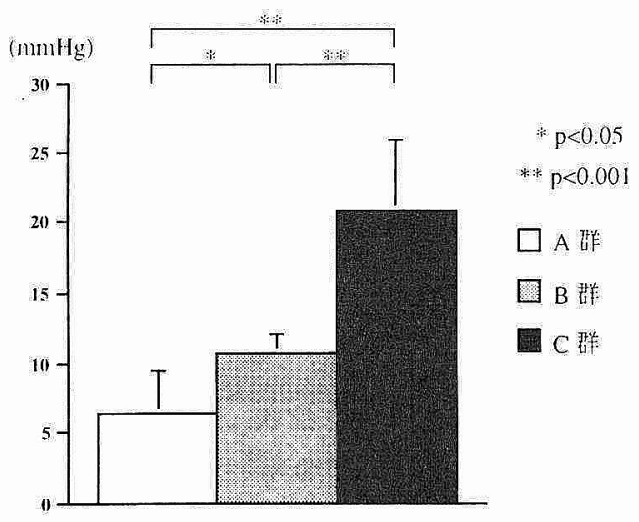

図 2 下部食道括紺筋圧 (LESP)

A 群 : 胃全摘兼有茎空腸間置術

B群：LES・幽門輪温存胃带全摘兼有茎空腸間置術 C群：対照

A 群 $6.4 \pm 3.1 \mathrm{mmHg}, \mathrm{B}$ 群 $10.7 \pm 1.4 \mathrm{mmHg}$, C 群 20.8土5.1 mmHg で, A 群では B 群, C 群よ り（それぞれ，p<0.05，p<0.001），また，B群 では C 群より有意に低下していた $(\mathrm{p}<0.001)$ 。

3. 下部食道 24 時間 $\mathrm{pH}$ 測定 (\% 時間 $\mathrm{pH}>7$ ) (図 3)

A 群 $66.1 \pm 30.0 \%$ ，B 群 $24.9 \pm 13.1 \%$ ，C 群 $5.9 \pm 8.4 \%$ で，A群ではB 群，C群より(それぞ れ， $\mathrm{p}<0.01 ， \mathrm{p}<0.001 ）$ ，また，B群では C 群よ り有意に長かった $(\mathrm{p}<0.01)$ 。

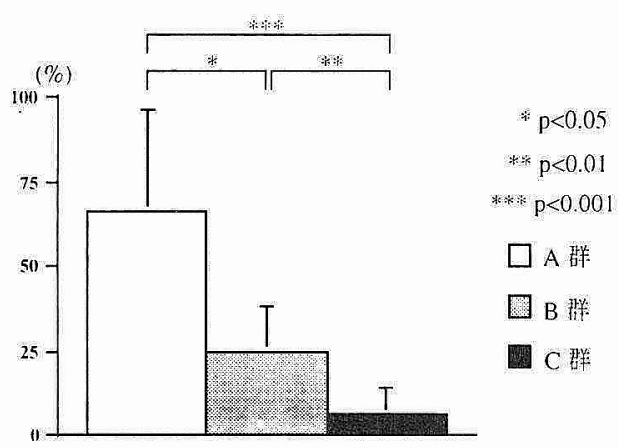

図 3 下部食道24時間 $\mathrm{pH}$ 側定（\%時間 $>7 ）$ $\mathrm{A}$ 群 : 胃全摘兼有茎空腸間置術

B 群：LES - 幽門輪温存胃亜全摘兼有茎空腸間置術 C群：対照

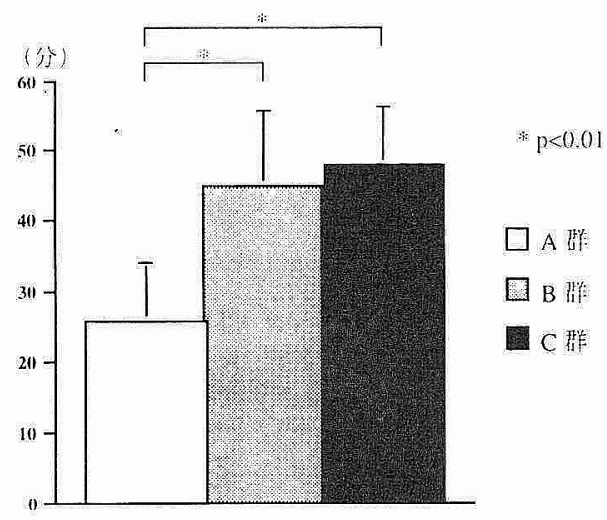

図 4 再建空腹内残存率 $50 \%$ 時間 A 群 : 胃全摘兼有茎空腸間置術

B 群：LES・幽門輪温存胃亜全摘兼有茎空腸間置術 C群：対照

\section{RI 法による再建空腸内容排出率}

(残存率 $50 \%$ 時間)（图 4)

A 群 $25.7 \pm 7.8$ 分, B 群 $44.9 \pm 10.8$ 分, C 群 $47.8 \pm 8.4$ 分であり， A 群では B 群, C群より有 意に早かった(それぞれ， $\mathrm{p}<0.01) 。$

\section{5. 血中ガストリン值}

\section{1) 空腹時 (図 5)}

A 群 $43.0 \pm 9.2 \mathrm{pg} / \mathrm{m} l, B$ 群 $60.9 \pm 8.0 \mathrm{pg} / \mathrm{m} l$, $\mathrm{C}$ 群 $93.0 \pm 17.9 \mathrm{pg} / \mathrm{m} l$ であり, A 群は B 群, C 群 より（それぞれ， p<0.01），また，B群は C 群よ り有意に低值を示した $(\mathrm{p}<0.01)$ 。

2）経口搨取 15 分後（図 6) 
早期胃癌にま引る下部食道括約筋・幽門輪温存胃亜全摘術康有茎空腸間置術の病態生理学的検討

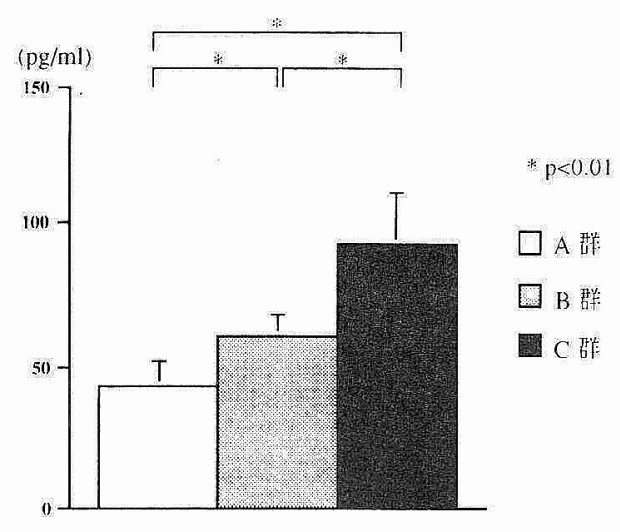

図 5 空腹時血中ガストリン值

A群：胃全摘兼有茎空腸間置術

$\mathrm{B}$ 群：LES・幽門輪温存胃要全摘兼有茎空腸間置術 C群：対照

A 群 $51.2 \pm 8.7 \mathrm{pg} / \mathrm{ml}$, B 群 $80.1 \pm 12.2 \mathrm{pg} /$ $\mathrm{m} l, \mathrm{C}$ 群 $122.4 \pm 15.7 \mathrm{pg} / \mathrm{m} l$ であり，A群はB

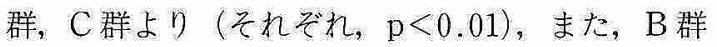
は C 群より有意に低值を示した $(\mathrm{p}<0.01)$ 。

\section{考察}

胃癌に対する胃全摘術では，噴門・幽門括約筋 機構，胃固有粘膜，迷走神経などが切除されるた め, これらの脱落による解剖生理学的変化と周囲 臓器との相関に変化が生しる ${ }^{10)}$ 。すなるち, 術前に ない新しい病態が作られることにより，胃手術後 障害を招き，術後長期間に渡って QOLの低下を 示すことがある。そこで，胃全摘術後の再建にお いては，まず食物が十二指腸を通過することが， 十二指腸粘膜を刺激して，gastrin， secretin， glucagon, gastric inhibitory polypeptide (GIP), CCK, pancreatic polypeptide (PP) などの消化 管ホルモン分泌させる。ついで，これらが胆汁 や膵汁などを分㳴させる結果，消化液と食物とが 良く混和されて，栄養素の消化吸収が効率良く行 われるとされる ${ }^{4,11 \sim 14)}$ 。しかし, 有茎空腸間置術が 行われても術後の逆流性食道炎や早期染ンピング 症候群に恼まされる症例も存在する ${ }^{15 \sim 21) 。 そ こ て ゙, ~}$ これらの胃手術後障害の発生を子防する目的で胃 全摘後の機能温存手術として，幽門括約筋温存胃 亜全摘兼有茎空腸間置術が一部の施設で行われて

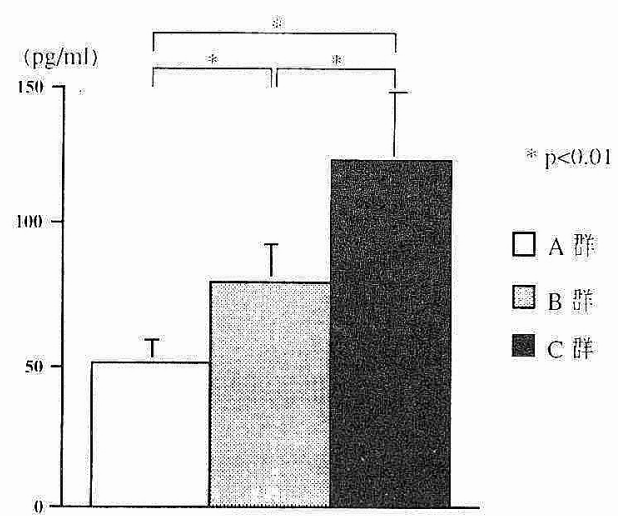

図 6 経口掑取 15 分後の血中ガストリン值 A 群 : 胃全摘兼有茎空腸間置術

B群：LES・幽門輪温存胃覀全摘兼有茎空腸間置術 C群：対照

いる。本術式は1975 年 Maki ら ${ }^{7}$ にり発表され たもので，幽門を $1.5 \mathrm{~cm}$ 残して近側胃切除を行 い，食道と残胃の間に約 $40 － 50 \mathrm{~cm}$ の空腸を有荎

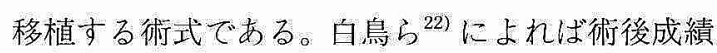
は逆流性食道炎 $6 \%$ ，早期ダンピング症候群 $0 \%$ の発生率であったとされている。一方，幽門輸を 温存しない有茥空腸間置術後の逆流性食道炎と早 期ダンピング症候群の発生頻度は, 前者 $14.3 \sim 58.0 \%^{3,15,20,21)}$, 後者 $12.5 \sim 31.0 \%^{3,6,22)}$ とさ れている。これらの成績を考えると，幽門括約筋 温存胃亜全摘兼有茥空腸間置術は術後の逆流性食 道炎や早期ダンピング症候群の発生がきわめて少 なく優れた術式といえる。しかし，少数例ではあ るが, 逆流性食道炎の発生が認められており ${ }^{222}$, 著 者らは，幽門括約筋温存胃亜全摘兼有茎空腸間置 術の変法として, さらにLESを温存する術式を 考案した。そ己で, 今回, LES・幽門括約筋温存 胃巠全摘廉有茥空腸間置術 (以下, 括約筋温存術 と略す）の有用性を確かめるため，逆流性食道炎 と早期ダンピング症候群の発生率に関して，括約 筋非温存術である胃全摘兼有茥空腸間置術と病態 生理学的な比較検討を試みた。なお，間置空腸の 長さは，それが $35 \sim 40 \mathrm{~cm}$ あれば逆流性食道炎の 発生は少ないという従来の報告 ${ }^{17)}$ に基づき $40 \mathrm{~cm}$ とした。

著者らの成績では，直接問診法による逆流性食 
道炎と早期ダンピング症候群の発生は, 括約筋非 温存術例では前述したごとく今までの報告と同様 の頻度でみられたが，括約筋温存術例においては 両者とも認められなかった。

噴門部逆流防止機構は, LES, 胃斜走筋, 胃食 道粘膜接合貿壁, 横隔食道靶帯, 横隔膜脚, His 角, 胃泡などが存在し調節されているが，特にLES が重要な働きをしている ${ }^{21,22)}$ と言われている。 $\mathrm{D}_{2}$ リンパ節郭清を伴う胃全摘術では，下部食道切除 とリンパ節郭清により噴門部括約筋機構がすべて 破壊される。このため腸内容などが食道内へ逆流 しやすくなり, 逆流性食道炎の発生をみる。胃全 摘後の逆流性食道炎は胆汁や膵液の食道への逆流 が関与しており，アルカリ性食道炎と呼ばれてい $3^{24)}$ 。

最近，この逆流性食道炎の病態を検討するため に, 食道内圧検査や 24 時間 $\mathrm{pH}$ 測定検査が行われ ている。食道内圧検查には perfusion open tip 法 が主に用いられ，カテーテルを胃や再建空腸など から食道へ引き抜くことにより描かれる曲線か ら, 昇圧帯部の圧 (LESP) と長さ (LESL) を測 定する。胃全摘後の症例では食道内压の低下と昇 圧帯の長さの短縮が認められ, 食道切除の長さが

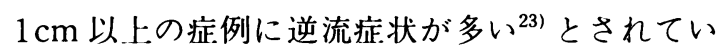
る。また, 中村ら ${ }^{22)}$ は, 食道切除長が長くなるに つれて, LESL と LESP は低下し, 食道切除長が $3 \mathrm{~cm}$ を越すと昇圧帯部は出現しなくなると報告 している。なお, 前川 (2) $^{2}$ 食道胃粘膜接合部から 口側 $1 \mathrm{~cm} の$ 食道が LES として重要な役割をし ており，迷走神経はあまり影響を及ぼしていない と報告している。一方, 食道の生理的な検査法と して挙げられている 24 時間 $\mathrm{pH}$ 測定検査 ${ }^{24)}$ で は, 胃全摘後のアルカリ性食道炎は食道内 $\mathrm{pH}$ が 7 以上になって生じる ${ }^{25 \sim 27)}$ とされ, またその際, 橋 本ら ${ }^{25)}$ は, 食道内 $\mathrm{pH}$ が 7 以上になる時間の割合 は $100 \%$ であったと報告している。さらに，山本 $ら^{20)}$ は, 胃全摘後における逆流性食道炎症例で は, 食道内 $\mathrm{pH}$ が 7 以上となる時間の割合が長く, びらん・潰瘍型を呈する症例では, 食道内 $\mathrm{pH}$ が 8 以上となる時間の割合が長かったとしている。 著者らの成績においては, 括約筋温存術例では, 食道は食道胃粘膜接合部から残しているが, 食道
内圧検査におけるLESL と LESP ともに, 括約筋 非温存術例に比較して明らかにLES として存在 した。また， 24 時間 $\mathrm{pH}$ 測定検査でも下部食道内 $\mathrm{pH}$ が 7 以上になる割合が, 明らかに括約筋非温 存術例に比較して低かった。これらのことから， LES を温存することは胃全摘術後逆流性食道炎 の子防に有用と考えられた。

なお，逆流症状があっても必ずしも内視鏡的逆 流性食道炎をともなっているとは言えない。すな わち, 山本ら ${ }^{20)}$ は, 逆流性食道炎症状を有する症 例の $72.7 \%$ のみに内視鏡的に食道炎を認め, 必ず しも自覚症状と内視鏡所見の一致をみるわけでは ないと報告している。このことは，胃全摘後に食 道自体の機能異常が生じたことによるとされてい $3^{27,28)}$ 。著者らも逆流性食道炎症状を有するが内 視鏡所見が正常であった 1 症例については，今後 食道運動機能異常の有無を調べる必要があると考 えている。

幽門輪は, 食事内容の十二指腸への急速排出や 十二指腸内容の逆流を防いでいる ${ }^{29 \sim 31)}$ 。特に食事 内容の十二指腸への急速排出防止は, 早期多ンピ ング症候群の予防となるとされている。白鳥ら ${ }^{22)}$ は, 胃全摘兼有茎空腸間置術と幽門温存胃严全摘 兼有茎空腸間置術例において， ${ }^{99 \mathrm{~m}} \mathrm{Tc}$ を使用した RI 法による排出テストで, 代用胃である有茎空腸 より排出動態を観察した結果, 前者では早期に急 速排出がみられたが, 後者ではほぼ正常人の排出 パターンであったと報告している。著者らの成績 では，括約筋温存術例では ${ }^{99 \mathrm{~m}} \mathrm{Tc}$ スズコロイドを 用いた全粥の排出テストで再建空腸 $50 \%$ 残存時 間が，正常例と近似しており，また，括約筋非温 存術例では括約筋温存例に比較してそれが明らか に短縮していた。

最後に血中ガストリン值の変動について検討す る。胃前庭部には $\mathrm{G}$ 細胞があり，ガストリンを分 泌し胃酸・ペプシン・脺酵素などの分泌, LES ・ 胃腸管・胆囊の収縮などの調節を行ってい

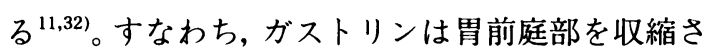
せることにより，食物を胃から十二指腸へ排出さ せ，同時にLES を収縮させ胃内容の食道への逆 流を防止し, 逆流性食道炎の発生を予防している ことが報告 ${ }^{22)}$ されている。なお，十二指腸にも $\mathrm{G}$ 
早期胃癌における下部食道括約筋・幽門輪温存胃亚全摘術兼有茥空腸間置術の病態生理学的検討

細胞があり，ここからもガストリンが分必されて いる ${ }^{11)}$ 。したがって, 胃全摘術後に食物を十二指腸 を通過させる空腸間置術は, Roux-en Y 術より生 理的と考えられている ${ }^{5,6,11)}$ 。著者らの成績では, 血 中ガストリン值は，括約筋温存術例が括約筋非温 存術例と比較して明らかに, 空腹時と食事負荷後 15 分值ともに高かった。このことは，括約筋温存 術例では幽門を $1.5 \mathrm{~cm}$ 残した（幽門輪から $1.5 \sim 2.0 \mathrm{~cm}$ の幽門を残すことにより，その部分 の迷走神経を温存する，しないにかかわらず再建 空腸内容のうっ滞をきたさないという報告によっ $\left.た^{33)}\right)$ ことで, 前庭部の $\mathrm{G}$ 細胞からのガストリン の分泌が残っていることによると考えられた。

以上, 括約筋温存術は, 括約筋非温存術に比較 して逆流性食道炎や早期ダンピング症候群の発生 を防止可能であり，また，ガストリン分必なども 生理的と考之られ術後の QOL 維持に適する機能 温存胃手術と思われる。なお, 有茎空腸そのもの を間置移植するだけの代用胃では, 胃本来の貯留 能が不十分である。そこで, 今後代用胃として J 型 囊 ${ }^{34 \sim 36)}$ を用いて検討するつもりである。また，最 近, 教室での $\mathrm{m}$ 癌 91 例の検討において,リンパ節 転移をまったく認めなく，したがって，今後 $\mathrm{m}$ 癌 ではリンパ節郭清を行わず迷走神経の温存を図り たいと考えている。

\section{おわりに}

早期胃癌に対する QOLの向上を目的として, LES ・幽門輪温存胃严全摘兼有茎空腸間置術を 行い，逆流性食道炎や早期ダンピング症候群など の胃手術後障害を中心に胃全摘兼有茎空腸間置術 と比較し，その有用性について機能面を中心に病 態生理学的検討を加えた。

\section{文献}

1）渡部洋三：ダンピング症候群. 青木照明, 島津久 明, 関根 毅, 渡部洋三, 胃手術後障害のすべて, 南汇堂, 東京, 1987, 126-166

2）関根 毅：逆流性食道炎. 青木照明, 島津久明, 関根 毅, 渡部洋三, 胃手術後障害のすべて, 南 江堂, 東京, 1987, 256-268

3) 今田敏夫, 山本祐司, 高橋 誠, 他: 胃全摘術後
の再建法の違いによる術後の栄養捸取と後遺症 の評価. Medical Postgraduates 33：25-29, 1995

4）富田凉一, 黒須康彦, 青木信彦, 他：胃癌におけ る胃全摘術（食道空腸 Roux-en Y 吻合）後の挙 上空腸運動について. 日大医誌 $52 ： 521-526$, 1993

5) Miholic J, Meyer HJ, Kotzerke J, et al : Empting of the gastric substitute after total gastrectomy. Ann Surg 210: 165-172, 1989

6）亀川仁，神賀正博, 星川 匡, 他：空腸間置と その生理的意義. 手術 11 : 1595-1605, 1990

7) Maki $T$, Shiratori $T$, Sekine $T$, et al: Application of Maki procedure to case of total gastrectomy. Gastroenterol Surg 9 : 316-319, 1975

8）上西紀夫, 大原 毅：ダンピング症候群. 外科診 療 $31: 1120-1128,1989$

9）富田凉一, 黑須康彦, 阿部義蔵, 他：幽門側胃亜 全摘術後早期ダンピング症候群における motilin 值の変動. 三好秋馬, 消化管ホルモン (XIII), 医学図書出版, 東京, 1995, p. 239-243

10）武藤輝一：胃切除後の病態. 武藤輝一, 胃切除後 の病態と治療一最近の進歩, 消化器病セミナー 35, へるす出版, 東京, $1989,1-5$

11）杉川 貢，門口幸彦：胃切除後の消化管ホルモ ン分泌の変化. 武藤輝一, 胃切除後の病態と治療 一最近の進歩, 消化器病セミナー 35 , へるす出 版, 東京, 1989，23-35

12）伏木 亨, 井上一知：食物と消化管ホルモン. 井 上一知, 戸部隆吉, 消化管ホルモン一最近の進 歩, 消化器病セミナー 37 , へるす出版, 東京, 1989，128-136

13）三隅厚信, 原田和則, 水本誠一, 他：胃手術と術 後の消化管ホルモン動態. 日外会誌 $92 ： 1175$ 1179，1991

14）前田迪郎，具原信明：胃全摘後の空腸間置によ 万再建術。外科診療 8：1013-1017， 1992

15）田中乙雄, 武藤輝一：胃全摘術後の長期管理. 消 外 $6: 1467-1471,1983$

16）平井敏弘, 荒谷清司, 吉中 建, 他：胃全摘術の 術後愁訴に関する検討. 癌の臨 $33: 258-264$, 1987

17）田中乙雄, 鈴木 力, 武藤輝一：空腸間置による 
再建術式. 手術 $44: 1589-1594 ， 1990$

18）高山澄夫, 青木照明, 平井勝也, 他 : 再建法の選 択と臨床評価一その 1-Roux-en Y 法. 外科診 療 8:997-1001, 1992

19）長町幸雄：胃全摘術一適応と再建術式の評価一 結腸間置術。外科診療 $34: 1033-1041,1992$

20）山本裕司, 天野富薫, 今田敏夫, 他：胃全摘後に 発生する逆流性食道炎症例の検討。日臨外医会 誌 $54: 874-878,1993$

21）中村豊英, 生田目公夫：食道機能検査からみた 胃全摘術後の逆流性食道炎についてーとくに lower esophageal high pressure zoneに及ぼす 影響一。 日消外会誌 $26: 1913-1920,1993$

22）白鳥常男, 中谷勝紀：噴門癌に対する幽門温存 胃亜全摘兼有茥空腸移植術. 消外 6:14431448,1983

23）前川憲昭：胃全摘後の食道機能に関する臨床的 研究. 大阪医会誌 $37: 479-498,1988$

24) Singh P, Colin-Jones DG: Simultaneous two level esophageal $\mathrm{pH}$ monitoring in healthy controls and patients with esophagitis: comparision between two position. Gut 35 : 304-308, 1994

25）橋本邦夫, 杉山 貢, 片村 宏: 胃手術後逆流性 食道炎の病態と治療方針. 消化器科 $13: 416$ 422,1990

26）内田雄三, 松本克彦, 野口 剛, 他: 胃手術後逆 流性食道炎の病因と対策. 外科診療 38 : 18189, 1996

27）中村正徳, 河野辰幸, 遠藤光夫：胃切除後の食道 運動機能評価と病態. 臨外 $49: 175-180,1994$

28）羽生信義, 大平洋一, 吉川良幸, 他：胃切除後の 上部消化管運動機能異常. J Smooth Muscle Res 31 : 244-248, 1995
29）中谷勝紀, 渡辺明彦, 中野博重, 他：早期胃癌に 対する幽門温存胃切除術. 手術 45：18251829, 1991

30) Kodama M, Koyama K : Indication for pylorus preserving gastrectomy for early gastric cancer located in the middle third of the stomach. World J Surg 15 : 628-634, 1991

31）富田凉一, 宗像敬明, 黒須康彦：幽門側胃垔全摘 術後症例における幽門輪温存の有無からみた残 胃排出能の検討. J Smooth Muscle Res 30:229 $-230,1994$

32) Tythat GNJ : Control mechanism of upper gastrointestinal motility. In: Tytgat GNJ (eds) Gastro-Oesophageal reflux and gastric stasis. Hong Kong: Toppan Printing HK 1991 : pp. 29-50

33）白鳥常男, 金泉年郁, 村田省吾, 他：胃運動機能 からみた胃潰瘍手術術式の評価。外科診療 $50: 421-430,1984$

34) Almedia ACM, Santos NMD, Aldeia FJ : Total gastrectomy for gastric cancer: Is reconstruction or a gastric replacement reservoir essential?. World J Surg 18: 883-888, 1994

35) Buhl K, Lehnert $T$, Schlag $P$, et al : Reconstruction after gastrectomy and quolity of life. World J Surg 19: 558-564, 1995

36) Schwarz A, Buchler $M$, Usinger $K$, et al : Importance of the duodenal passage and pouch volume after total gastrectomy and reconstruction with the Ulm pouch: Prospective randomized clinical study. World J Surg $20: 60-67,1996$ 